\title{
Pengaruh Kesehatan Lingkungan terhadap Perubahan Epidemiologi Demam Berdarah di Indonesia
}

\author{
Ribka Wowor \\ Fakultas Kesehatan Masyarakat Universitas Sam Ratulangi Manado \\ Email: ribkaladywowor@gmail.com
}

\begin{abstract}
In Indonesia, dengue hemorrhagic fever (DHF) is a serious health problem. Infection of dengue has occurred in Indonesia for the last two decades. It is a self limiting disease, however, its clinical manifestations has become worsened since several years ago. Epidemiologic pattern of dengue infection changes every year, and there is a peak of new cases every 10 years. Nowadays, adolescence and adult individuals belong to the high risk population of this infection. This epidemiologic changing of DHF is influenced by several environmental factors, inter alia: 1) increasing of human population; 2) uncontrolled urbanization; 3) no effective control of mosquitoes in endemic areas; and 4) modernized public transportation.
\end{abstract}

Keywords: environmental sanitation, epidemiology, dengue hemorrhagic fever

\begin{abstract}
Abstrak: Di Indonesia, demam berdarah dengue (DBD) masih merupakan masalah kesehatan masyarakat yang penting. Infeksi dengue terjadi secara endemis di Indonesia selama dua abad terakhir. Penyakit ini bersifat self limiting namun dalam beberapa tahun terakhir memperlihatkan manifestasi klinis yang semakin berat sebagai DBD dan frekuensi kejadian luar biasanya semakin meningkat. Pola epidemiologi infeksi dengue mengalami perubahan dari tahun ke tahun, jumlah kasus memuncak setiap siklus 10 tahunan. Kelompok usia yang terserang dengue berubah menjadi kelompok remaja dan dewasa. Perubahan epidemiologi DBD ini turut dipengaruhi oleh faktor kesehatan lingkungan. Faktor-faktor yang memengaruhi peningkatan dan penyebaran kasus DBD sangat kompleks yaitu, antara lain: 1) pertumbuhan penduduk yang tinggi dan cepat; 2) urbanisasi yang tidak terencana dan tidak terkendali; 3) tidak adanya kontrol vektor nyamuk yang efektif di daerah endemis; serta 4) peningkatan sarana transportasi.
\end{abstract}

Kata kunci: kesehatan lingkungan, epidemiologi, demam berdarah dengue

Infeksi dengue merupakan penyakit menular melalui nyamuk yang paling sering terjadi pada manusia dalam beberapa tahun terakhir sehingga masih merupakan masalah kesehatan dunia. Penyakit ini merupakan salah satu masalah kesehatan utama karena dapat menyerang semua golongan usia dan meyebabkan kematian khususnya pada anak dan kejadian luar biasa (KLB, wabah). Saat ini terlihat adanya kecenderungan kenaikan proporsi penderita demam berdarah dengue (DBD) pada orang dewasa. ${ }^{1}$
Beberapa dekade terakhir ini, insiden demam dengue (DD) menunjukkan peningkatan yang sangat pesat di seluruh penjuru dunia. Sebanyak dua setengah milyar atau dua perlima penduduk dunia berisiko terserang DD. Sebanyak 1,6 milyar (52\%) dari penduduk yang berisiko tersebut hidup di wilayah Asia Tenggara. WHO memperkirakan sekitar 50 juta kasus infeksi dengue setiap tahunnya. ${ }^{2}$

Di Indonesia, DD masih merupakan masalah kesehatan masyarakat yang penting. Infeksi dengue terjadi secara 
endemis di Indonesia selama dua abad terakhir dengan gejala yang ringan dan self limiting. Dalam beberapa tahun terakhir, penyakit ini memperlihatkan manifestasi klinis yang semakin berat sebagai DBD dan frekuensi kejadian luar biasanya semakin meningkat. Pola epidemiologik infeksi dengue mengalami perubahan dari tahun ke tahun, dan jumlah kasus memuncak setiap siklus 10 tahunan. Dari tahun 1968 sampai tahun 2008 angka kesakitan DBD terus mengalami peningkatan. Tingginya angka kasus kesakitan yang disebabkan oleh penyakit ini menurut WHO merupakan petunjuk bahwa masalah kesehatan masyarakat masih merupakan beban. ${ }^{3}$

\section{Penyebaran DBD di dunia}

Penyakit DBD yang disebabkan oleh virus dengue telah dikemukakan oleh David Bylon yang meneliti epidemi DBD yang berjangkit di Batavia pada tahun 1779 dan Benyamin Rush yang menulis tentang epidemi break bone fever ganas yang terjadi di Philadelphia pada tahun $1780 .{ }^{4}$

Penyakit DBD merupakan salah satu penyakit menular berbahaya yang dapat mengakibatkan kematian dalam waktu singkat dan sering menimbulkan wabah. Penyakit ini pertama kali ditemukan di Manila Filipina pada tahun 1953 dan selanjutnya menyebar ke berbagai negara, di antaranya Hanoi (1958), Malaysia (1962-1964), Calcutta (1963), dan Saigon (1965). Selanjutnya, dari kawasan Asia Tenggara DBD menyebar ke India, Maldivia, dan Pakistan, serta ke arah Timur ke Republik Rakyat Tiongkok. Pada saat ini DBD telah menyebar luas di kawasan Pasifik Barat dan daerah Karibia. ${ }^{5}$

Antara tahun 1975 dan 1995, DD/DBD terdeteksi keberadaannya di 102 negara di lima wilayah WHO, yaitu: 20 negara di Afrika, 42 negara di Amerika, tujuh negara di Asia Tenggara, dan empat negara di Mediterania Timur, serta 29 negara di Pasifik Barat. Seluruh wilayah tropis di dunia saat ini telah menjadi hiperendemis (keberadaan penyakit dengan tingkat insidensi yang tinggi dan terus menerus melebihi angka prevalensi normal dalam populasi dan ternyata menyebar merata pada semua usia dan kelompok) dengan ke empat serotipe virus dengue di wilayah Amerika, Asia Pasifik dan Afrika. Indonesia, Myanmar dan Thailand termasuk kategori A yaitu: KLB (wabah siklis) terulang pada jangka waktu antara 35 tahun. ${ }^{4}$ Dalam 50 tahun terakhir, kasus DBD meningkat 30 kali lipat dengan peningkatan ekspansi geografik ke negaranegara baru, dan dalam dekade ini, dari kota ke lokasi pedesaan. Penderitanya banyak ditemukan di sebagian besar wilayah tropis dan subtropis, terutama Asia Tenggara, Amerika Tengah, Amerika, dan Karibia. ${ }^{6}$

Virus dengue dilaporkan telah menjangkiti lebih dari 100 negara, terutama di daerah perkotaan yang berpenduduk padat dan pemukiman di Brazil dan bagian lain Amerika Selatan, Karibia, Asia Tenggara, dan India. Jumlah orang yang terinfeksi diperkirakan sekitar 50 sampai 100 juta orang, setengahnya dirawat di rumah sakit dan mengakibatkan 22.000 kematian setiap tahun; diperkirakan 2,5 miliar orang atau hampir $40 \%$ dari populasi dunia tinggal di daerah endemis DBD yang memungkinkan terinfeksi virus dengue melalui gigitan nyamuk setempat. ${ }^{2}$

\section{Penyebaran DBD di Indomesia}

Di Indonesia, penyakit ini pertama kali dilaporkan pada tahun 1968 di Surabaya sebanyak 58 orang penderita dengan kematian 24 orang $(41,3 \%)$, akan tetapi konfirmasi virologik baru didapat pada tahun 1972. Sejak saat itu penyakit DBD cenderung menyebar ke seluruh tanah air Indonesia, sehingga sampai tahun 1980 seluruh provinsi di Indonesia, kecuali Timor-Timur telah terjangkit penyakit. Puncaknya pada tahun 1988 dengan incidence rate mencapai 13,45 per 100.000 penduduk. Pada tahun pertama diketahui infeksi dengue di Indonesia, dilaporkan 58 kasus di DKI Jakarta dan Surabaya (termasuk 24 kasus yang meninggal). Pada tahun 1970, 24 kasus dengue diidentifikasikan di antara 48 kasus anak tersangka dengue di Yogyakarta. Selanjutnya, 8 kasus 
diklasifikasikan DBD dan 2 kasus berkembang menjadi $\mathrm{SSD}^{6}{ }^{6}$ sedangkan KLB pertama dilaporkan terjadi tahun $1973 .^{7}$

Pada semua kasus sindrom syok dengue (SSD), tidak ditemukan hubungan antara serotipe dengue dan derajat beratnya penyakit, walaupun demikian tiga kasus fatal berhubungan dengan virus den-3. Satu tahun kemudian suatu KLB den-3 terjadi di Sleman, $40 \mathrm{~km}$ Utara Bantul, yang memiliki gejala ringan. Distribusi usia hampir mirip dengan wabah di Bantul, namun penyakitnya tidak seberat yang dilaporkan pada wabah di Bantul (kasus SSD di Bantul 37\% dan Sleman 13\%). ${ }^{3}$

\section{Penularan DBD}

\section{Vektor DBD di Indonesia}

Vektor DBD yang utama di Indonesia ialah Aedes aegypti yang keberadaannya hingga dewasa ini masih tersebar di seluruh pelosok tanah air. Hasil survei jentik yang dilakukan Depkes tahun 1992 di 7 kota di Pulau Jawa Sumatera dan Kalimantan, menunjukkan bahwa rata-rata persentase rumah dan tempat umum yang ditemukan jentik (Premis index) masih cukup tinggi. yaitu sebesar $28 \%{ }^{5}$

Nyamuk ini berasal dari Mesir yang kemudian menyebar ke seluruh dunia, melalui kapal laut dan udara. Nyamuk hidup dengan subur di belahan dunia yang mempunyai iklim tropis dan subtropis seperti Asia, Afrika, Australia dan Amerika. Nyamuk ini terdapat dimanamana, kecuali di wilayah ketinggian lebih dari 1000 meter di atas permukaan laut. Dewasa ini nyamuk $A$. aegypti ditemukan terutama di negara-negara yang terletak diantara garis $45^{\circ}$ Lintang Utara dan garis $35^{\circ}$ Lintang Selatan. Penyebaran nyamuk yang kosmopolit ini berkaitan erat dengan perkembangan system transportasi. ${ }^{8}$

A. aegypti tersebar luas di semua provinsi seluruh Indonesia. Selain ditemukan di kota-kota pelabuhan yang berpenduduk padat, spesies ini ditemukan juga di daerah perkotaan dan pedesaan yang jauh dari pelabuhan. Penyebaran dari pelabuhan ke desa ini dikarenakan larva $A$. aegypti terbawa transportasi yang mengangkut benda-benda berisi genangan air yang mengandung larva spesies ini. Nyamuk A. aegypti merupakan vektor penular utama virus dengue yang tersebar di rumah maupun tempat-tempat umum (TTU). Graham ialah sarjana pertama yang pada tahun 1903 dapat membuktikan secara positif peran nyamuk $A$. aegypti dalam transmisi dengue. ${ }^{7}$

\section{Mekanisme penularan}

Penularan DBD terjadi melalui gigitan nyamuk $A$. aegypti atau $A$. albopictus betina yang sebelumnya telah membawa virus dalam tubuhnya yang diperoleh dari penderita DBD lain. Nyamuk A. aegypti berasal dari Brasil dan Ethiopia dan sering menggigit manusia pada waktu pagi dan siang. Orang yang berisiko terkena DBD ialah anak-anak yang berusia di bawah 15 tahun dan sebagian besar tinggal di lingkungan lembab serta daerah pinggiran kumuh.

Penularan virus dengue terjadi melalui gigitan nyamuk yang termasuk subgenus Stegomya yaitu nyamuk $A$. aegypti dan $A$. albopictus sebagai vektor primer serta $A$. polynesiensis, A. scutellaris, dan A. niveus sebagai vektor sekunder. Selain itu juga terjadi penularan transeksual dari nyamuk jantan ke nyamuk betina melalui perkawinan serta penularan transovarial dari induk nyamuk ke keturunannya. Terdapat juga penularan virus dengue melalui transfusi darah seperti terjadi di Singapura pada tahun 2007 yang berasal dari penderita asimtomatik. Dari beberapa cara penularan virus dengue, yang paling tinggi ialah penularan melalui gigitan nyamuk A. aegypti. ${ }^{2}$

Sekali virus dapat masuk dan berkembang biak di dalam tubuh nyamuk, nyamuk akan dapat menularkan virus selama hidupnya (infektif) ke individu yang rentan selama menusuk/menggigit dan mengisap darah. ${ }^{3}$ Virus kemudian berkembang di dalam tubuh nyamuk selama 8-10 hari (inkubasi ekstrinsik) sebelum dapat ditularkan ke manusia lain saat menusuk/menggigit dan mengisap 
darah berikutnya. Lama waktu yang diperlukan untuk inkubasi ekstrinsik ini tergantung pada suhu lingkungan, khususnya suhu sekitar. ${ }^{4}$

Di dalam tubuh nyamuk, virus dengue tersebut akan berkembang biak dengan cara membelah diri dan menyebar ke seluruh bagian tubuh nyamuk. Sebagian besar virus berada di dalam kelenjar liur nyamuk. Dalam waktu satu minggu jumlahnya dapat mencapai puluhan atau bahkan ratusan ribu sehingga siap untuk ditularkan/dipindahkan kepada orang lain. Pada manusia, virus memerlukan waktu 4-6 hari (intrinsic incubation period) sebelum menimbulkan sakit. ${ }^{5}$

\section{Tempat potensial bagi penularan DBD}

Spesies A. aegypti merupakan nyamuk yang habitatnya di pemukiman dan habitat stadium pradewasanya pada bejana buatan yang berada di dalam ataupun di luar rumah yang airnya relative jernih. Nyamuk A. aegypti hidup dan berkembang biak di tempat-tempat penampungan air (TPA) untuk keperluan sehari-hari yang tidak langsung berhubungan dengan tanah, seperti: bak mandi/WC, minuman burung, air tandon, air tempayan/gentong, drum, ember, pot tanaman air, tanah padat yang mengeras serta barang-barang bekas di luar rumah seperti: kaleng, botol, ban bekas, potongan bambu, aksila daun, plastik, dan lain sebagainya. Kadang-kadang jentik dijumpai dalam talang air, lubang pohon, dan genangan air. Faktor-faktor yang memengaruhi perilaku $A$. aegypti meletakkan telurnya antara lain jenis dan warna penampungan air, kondisi airnya sendiri, suhu kelembaban, dan kondisi lingkungan setempat. Tempat air yang tertutup longgar lebih disukai sebagai tempat bertelur dibanding tempat yang terbuka. ${ }^{10}$

\section{Musim penularan dan penyebaran DBD}

Secara nasional penyakit DBD di Indonesia setiap tahun terjadi pada buan September s/d Februari dengan puncak pada bulan Desember atau Januari yang bertepatan dengan waktu musim hujan. Untuk kota besar seperti Jakarta, Bandung,
Yogyakarta, dan Surabaya musim penularan terjadi pada bulan Maret s/d Agustus dengan puncak terjadi pada bulan Juni atau Juli. ${ }^{5}$

Menurut laporan Departemen Kesehatan Republik Indonesia yang didapatkan selama pengamatan 20 tahun, umumya di Indonesia menunjukkan letusan DBD pada musim hujan. Populasi vektor meningkat karena sanitasi belum baik dan telur yang semula terkumpul di dalam penampungan air yang kering menetas setelah tergenang air. Pada musim hujan dimana jumlah nyamuk yang meningkat dan kelembaban udara yang tinggi akan meningkatkan aktivitas nyamuk untuk menggigit/menusuk. Kemungkinan kontak antara nyamuk dengan manusia juga meningkat karena pada musim hujan orangorang umumnya lebih banyak tinggal di dalam rumah. Selama musim hujan, jangka waktu hidup nyamuk diperkirakan lebih panjang, sehingga bila nyamuk tersebut mengandung virus dengue maka risiko penularan virus menjadi lebih besar. Dengan demikian dapat dipahami mengapa peningkatan jumlah kasus DD dan DBD ini umumnya terjadi pada musim hujan. ${ }^{11}$

\section{Perubahan epidemiologi DBD Gambaran epidemiologi}

Kasus infeksi dengue pertama di Indonesia dilaporkan pada tahun 1968 di kota DKI Jakarta dan Surabaya kemudian dilanjutkan dengan laporan dari Bandung dan Yogyakarta. Sejak saat itu tersangka kasus dengue dilaporkan oleh Departemen Kesehatan. Awalnya, angka kesakitan dilaporkan hanya di pulau Jawa dengan jumlah kasus yang terbatas. Pada awal tahun 1980-an, laju angka kesakitan meningkat dari 10000 sampai 30000 per tahun, dan sejak sepuluh tahun terakhir laju angka kesakitan telah meningkat dari 30000 s/d 60000 kasus per tahun. Meningkatnya kasus dengue secara bermakna dilaporkan terjadi pada tahun 1973 dan 1988, dan pada tahun 1998 dan 2004 dilaporkan berturut-turut 73133 dan 78680 kasus. Kini, infeksi dengue telah menyebar merata di antara 33 provinsi di 
Indonesia, dengan latar belakang interepidemis antara 10000- 25000 kasus setiap tahun. $^{3}$

Kejadian luar biasa dengue pertama dilaporkan terjadi tahun 1973. Dari 10189 kasus yang dilaporkan, 6225 kasus didiagnosis di Semarang, tidak didapatkan data mengenai derajat beratnya penyakit. Pada tahun berikutnya dilaporkan kejadian luar biasa di luar pulau Jawa yaitu di Manado, Sulawesi Utara. Suatu epidemik demam berdarah dengue dengan derajat berat dan viremia tinggi dilaporkan di Bantul, Jawa Tengah pada akhir tahun 1976 dan awal 1977.7

Selama periode November 1997 sampai 1998, kejadian luar biasa DBD terjadi kembali di seluruh wilayah Indonesia. Sebelas provinsi yang terlibat dan semua KLB terjadi di daerah perkotaan. Kejadian luar biasa dimulai bulan November 1997 di Jambi, Sumatra Selatan, dan Lampung, kemudian KLB menyebar ke seluruh provinsi di Sulawesi, Nusa Tenggara Barat, dan Timor Timur, berlanjut ke Ambon, Maluku, dan akhirnya mencapai Jakarta pada bulan Maret 1998. Rerata attack rate 1,2 per 1000 populasi, tertinggi terjadi di Palembang, Sumatra Selatan (1,6 per 1000 populasi). Kecenderungan terjadi KLB di Palembang pada tahun 1998 yang menunjukkan peningkatan kasus dengue mencapai tiga kali lipat antara bulan Januari sampai April. Tampak perubahan transmisi epidemik yaitu dari kelompok usia 5 tahun ke kelompok usia remaja dan dewasa muda yang terinfeksi dengue. ${ }^{3}$

Pada bulan April 2001, KLB kedua terjadi di Papua. Di Merauke, suatu penelitian kasus kontrol retrospektif dilakukan terhadap 15 kasus DBD akut, 37 kasus konvalesen, dan 32 kasus kontrol. Antibodi IgM virus dengue ditemukan pada $27 \%$ kasus klinis akut, $30 \%$ pada kasus konvalesen, dan hanya $3 \%$ pada kasus kontrol. Dengue virus den-3 merupakan satu-satunya serotipe virus dengue yang terdeteksi dengan RT-PCR, semua dari sampel kasus akut. Dari evaluasi catatan medik, 172 tersangka kasus teridentifikasi.
Angka kematian berkisar 1,2\% dari semua kasus tersangka dengue. ${ }^{11}$

Pada tahun 2004, terjadi KLB lagi yang mulai menyebar ke seluruh Indonesia, dengan kota Jakarta yang paling banyak melaporkan kasus. Berdasarkan laporan WHO, 78690 kasus dan lebih dari 900 kematian dilaporkan di Indonesia pada tahun tersebut. Penelitian kohort dilakukan pada 272 pasien yang dirawat untuk mengonfirmasi etiologi penyakit di 10 rumah sakit yang berlokasi di Indonesia. ${ }^{4}$ Infeksi dengue ditemukan pada $66,2 \%$ dari semua kasus, 55,6\% dengan $\mathrm{DD}, 17,2 \%$ dengan DD disertai manifestasi perdarahan, dan 27,2\% dengan DBD. Dari kasus DBD yang dikonfirmasi, $82,5 \%$ terbukti mengalami infeksi sekunder. Isolasi virus dilakukan pada 28 serum akut dari kasus yang secara serologik positif dan teridentifikasi keempat serotipe dengue. Infeksi dengue lebih banyak ditemukan pada kelompok usia lebih dari 15 tahun. ${ }^{12}$

\section{Angka kesakitan dan kematian DBD}

Setelah terjadinya KLB DBD nasional pada tahun 1988, kasus DBD di Indonesia menurun tajam. Hal ini mungkin berkaitan dengan kebijaksanaan program DBD yang dikembangkan selama satu dasawarsa terakhir. Insidens rate DBD pada tahun 1989 (awal Repelita V) turun menjadi 6,1 per 100.000 penduduk kemudian pada tahun kedua dan ketiga mengalami peningkatan menjadi 12,73 dan 11,56 per 100.000 penduduk, dan pada tahun 1993 (akhir Repelita V) incidence rate mengalami penurunan menjadi 9,2 per 100.000 penduduk. Pada tahun 1994 incidence rate demam berdarah meningkat kembali dari 9,4 menjadi 18,4 per 100.000 penduduk pada tahun 1995 , dan 22,96 per 100.000 penduduk pada tahun 1996. Wilayah Dati II terjangkit DBD bertambah luas yaitu dari 201 Dati pada tahun 1988 menjadi 211 Dati II pada tahun $1996 .{ }^{5}$

Walaupun angka kesakitan penyakit ini cenderung meningkat dari tahun ke tahun namun sebaliknya angka kematian cenderung menurun. Hal ini disebabkan semakin dininya penderita mendapat 
penanganan tenaga kesehatan di daerahdaerah. Meskipun demikian pada tahun 1996 terdapat beberapa program di Indonesia yang angka kematiannya masih cukup tinggi $(>5 \%)$ yaitu provinsi Aceh, Sumatera Selatan, Kalimantan Barat, Kalimantan Tengah, Kalimantan Timur, Sulawesi Tenggara, Lampung, Nusa Tenggara Barat, dan Timor-Timor. Menurut tim observasi DBD di provinsi Sumatera Selatan dan Kalimantan Barat, tingginya angka kematian salah satunya diakibatkan oleh daerah tersebut ketat dalam menentukan diagnosis DBD (penderita tersangka DBD yang tidak dirawat di rumah sakit tidak dimasukkan dalam kasus DBD), sehingga jumlah kasus DBD dalam perhitungan Case Fatality Rate (CFR) menjadi kecil dan akibatnya CFR menjadi besar. ${ }^{6}$

Di Indonesia, CFR menurun dengan stabil dari $41 \%$ pada tahun 1968 menjadi kurang dari $2 \%$ sejak tahun 2000 , menurun menjadi $1,21 \%$ pada tahun 2004 , dan pada tahun 2008 angka kematian sudah menurun menjadi 0,86\%. Pada tahun 2008 angka kesakitan tertinggi terjadi di provinsi DKI Jakarta $(303,5)$, Kalimantan Timur $(174,6)$, dan Bali (170,1). Angka kematian tertinggi terjadi di provinsi Maluku (3,66\%), Kalimantan Barat $(3,53 \%)$, dan Nusa Tenggara Timur $(2,87 \%){ }^{3}$

Dari penderita DBD yang tercatat selama ini yang tertinggi ialah pada kelompok usia kurang dari 15 tahun (95\%) dan mengalami pergeseran dengan adanya peningkatan proporsi penderita pada kelompok usia 15-45 tahun, sedangkan proporsi penderita DBD pada kelompok usia >45 tahun sangat rendah seperti yang terjadi di Jawa Timur berkisar 3,64\%. ${ }^{13}$

Golongan usia yang paling banyak menderita DBD ialah anak masa sekolah usia 5-10 tahun, kemudian diikuti oleh golongan usia di bawah 5 tahun dan selanjutnya oleh golongan usia 10-15 tahun. Dalam dekade 30 tahunan terakhir ini telah menunjukkan adanya pergeseran usia penderita ke kelompok usia yang lebih tua dan bertambahnya kasus DBD pada orang dewasa. ${ }^{14}$ Begitu juga dari hasil studi epidemiologi DBD pada orang dewasa menyatakan bahwa golongan usia yang paling banyak menderita DBD ialah dewasa muda usia 15-20 tahun, kemudian diikuti oleh golongan usia 20-25 tahun, lalu diikuti oleh golongan usia 25-30 tahun, seterusnya oleh golongan usia di atas 30 tahun. ${ }^{15}$

\section{Penyebab perubahan epidemiologi DBD}

Demam dengue dan DBD merupakan masalah kesehatan masyarakat yang penting di Indonesia sejak ditemukan pada tahun 1968. Epidemiologi DBD di Indonesia telah berubah dengan meningkatnya jumlah kasus dari seluruh 33 provinsi. Kecenderungan dari KLB infeksi dengue mengikuti pola siklik yang iregular dengan latar belakang endemik. Kelompok usia yang terserang dengue berubah menjadi kelompok remaja dan dewasa. Pada periode 1979-1984 rerata usia kasus DBD di Jakarta ialah 4-11 tahun. Data Departemen Kesehatan menunjukkan setelah tahun 1984 insidens kelompok usia lebih dari 15 tahun meningkat dari tahun ke tahun hingga sekarang. Hal ini juga terjadi di beberapa negara di Asia yang menunjukkan bahwa insidens kasus DBD mengalami pergeseran ke kelompok usia remaja.

Data derajat beratnya DBD tidak dilaporkan sehingga sulit menentukan apakah terjadi perubahan rasio dari DD, DBD, dan SSD. Selain kewaspadaan, peningkatan alat dan fasilitas diagnostik juga membaik sehingga membantu pelaporan kasus. Kejadian luar biasa lebih dikenal lebih dini, dan uji diagnostik lebih sensitif dan spesifik membantu korfirmasi diagnosis. Definisi kasus berdasarkan WHO juga digunakan oleh Depkes, dengan kriteria diagnosis klinis dan laboratorium. Disebutkan bahwa semua kasus tersangka dan konfirmasi harus selalu dilaporkan. Karena tidak semua sarana kesehatan memiliki fasilitas laboratorium untuk konfirmasi, maka laporan kasus tidak selalu menggambarkan situasi yang sebenarnya. Pada negara dengan banyak kejadian epidemik dan transmisi endemik tinggi maka jumlah kasus sebenarnya lebih besar. 
Estimasi angka kematian DBD dari data surveilans didapatkan lebih rendah dari data penelitian sampel tunggal, yang mendukung adanya under-reporting atau salah menentukan klasifikasi kematian. World Health Organization memperkirakan bahwa data surveilans hanya menangkap sepertiga dari total kasus DBD, sehingga insidens DBD di dunia dapat mencapai sekitar 1,5 juta kasus per tahun, bukan 0,5 juta kasus seperti yang diperkirakan oleh WHO. $^{2}$

Transmisi epidemik dipengaruhi oleh vektor nyamuk, populasi yang secara imunologik rentan, dan terdapat sirkulasi virus dengue. Berbagai strain virus dengue dan kemungkinan timbulnya virus dengue baru dan lebih virulen meningkatkan insidens epidemik DBD. Beberapa penelitian di Indonesia menunjukkan hubungan antara DBD berat dengan infeksi sekunder. Di Indonesia semua serotipe dapat teridentifikasi dan den-3 merupakan serotipe yang paling sering menyebabkan penyakit berat dan fatal. ${ }^{3}$

Faktor-faktor yang dapat memengaruhi peningkatan dan penyebaran kasus DBD sangat kompleks, yaitu: 1) pertumbuhan penduduk yang tinggi dan cepat; 2) urbanisasi yang tidak terencana dan tidak terkendali; 3) tidak adanya kontrol vektor nyamuk yang efektif di daerah endemis; dan 4) peningkatan sarana transportasi. Pertumbuhan penduduk yang tinggi dan cepat ini tidak disertai dengan tersedianya pemukiman yang layak dari segi higienis dan sanitasi, sehingga akan menghasilkan pemukiman yang rawan dengan sanitasi yang buruk serta pengelolaan sampah yang tidak efektif. Pemukiman seperti ini memberikan tempat yang baik bagi perkembangbiakkan berbagai vektor dan penyakit, termasuk nyamuk Aedes spp. Begitu juga urbanisasi yang tak terkontrol dengan sistem pembuangan sampah cair dan padat yang tidak baik, dan peningkatan frekuensi penerbangan udara serta penggunaan tempat air kemasan akan meningkatkan penyebaran penyediaan tempat perindukan nyamuk. ${ }^{16}$

Mudahnya transportasi antar kota dengan desa menyebabkan mobilitas penduduk menjadi meningkat, sehingga memungkinkan terjadinya penyebaran virus dengue dari daerah perkotaan ke pedesaan. Berdasarkan hal tersebut maka dimungkinkan suatu daerah yang semula non-endemis menjadi endemis jika daerah tersebut merupakan daerah reseptif, artinya vektor DBD yaitu nyamuk Aedes spp juga ditemukan di daerah tersebut. ${ }^{17}$

\section{Pengaruh kesehatan lingkungan}

Epidemi dengue dipengaruhi beberapa faktor, yaitu: faktor lingkungan, faktor biologi, dan demografi. Insidens dengue berhubungan dengan cuaca yang hangat dan kelembaban tinggi. Suhu yang tinggi dapat merangsang perkembangbiakan vektor dan perilaku nyamuk menggigit. Pergeseran kelompok usia, penyebaran ke pedesaan, faktor penentu sosial dan biologi dari ras dan jenis kelamin yang rentan berpengaruh terhadap pelayanan kesehatan. Pola peningkatan kasus infeksi dengue den3 secara epidemiologi berhubungan dengan musim hujan karena penampungan air hujan akan menjadi tempat perkembangbiakan nyamuk. $^{3}$

Kepadatan populasi nyamuk $A$. aegypti akan meningkat di musim hujan, dimana banyak terdapat genangan air yang merupakan tempat perindukannya. Telur yang semula terkumpul dalam penampungan air kering, menetas setelah tergenang air sehingga pada musim hujan jumlah nyamuk meningkat. Iklim tropis seperti Indonesia merupakan faktor suburnya perkembangan populasi nyamuk. ${ }^{5}$

Sebuah penelitian di Thailand menyebutkan bahwa suhu dan kelembaban udara serta curah hujan memiliki pengaruh yang bermakna terhadap angka insiden DBD. Dalam sebuah penelitian di Kecamatan Cilincing, Jakarta Utara, dilaporkan jumlah hari hujan, suhu, dan kelembaban udara berhubungan secara bermakna dengan angka insiden DBD. Di Kecamatan Penjaringan ditemukan adanya hubungan bermakna antara kecepatan angin dengan angka insiden DBD. ${ }^{1}$

Pola berjangkit infeksi virus dengue 
dipengaruhi oleh iklim dan kelembaban udara. Pada suhu yang panas $\left(28^{\circ}-32^{\circ} \mathrm{C}\right)$ dengan kelembaban yang tinggi, nyamuk Aedes spp. akan tetap bertahan hidup dalam jangka waktu yang lama. Pola siklus peningkatan penularan terjadi pada musim hujan. Interaksi antara suhu dan turunnya hujan ialah determinan penting dari penularan dengue, karena makin dinginnya suhu memengaruhi ketahanan hidup nyamuk dewasa, yang selanjutnya memengaruhi laju penularan. Selain itu turunnya hujan dan suhu juga dapat memengaruhi pola makan, reproduksi nyamuk, dan meningkatkan kepadatan nyamuk vektor. ${ }^{16}$

Selain faktor lingkungan alamiah di atas, faktor lainnya yang termasuk dalam lingkungan ialah angka bebas jentik (ABJ) dan kepadatan penduduk. Angka bebas jentik merupakan salah satu indikator keberhasilan program pemberantasan vektor penular DBD. Faktor risiko penularan DBD ialah antara lain pertumbuhan penduduk perkotaan yang cepat, mobilisasi penduduk karena membaiknya sarana dan prasarana transportasi, dan terganggu atau melemahnya pengendalian populasi yang memungkinkan terjadinya KLB. Kepadatan penduduk dapat meningkatkan penularan kasus DBD yaitu dengan semakin banyak manusia maka akan semakin besar peluang nyamuk $A$. aegypti menggigit sehingga penyebaran kasus DBD dapat menyebar dengan cepat dalam suatu wilayah. ${ }^{1}$

Faktor risiko lainnya ialah kemiskinan yang mengakibatkan orang tidak mampu untuk menyediakan rumah yang layak dan sehat, pasokan air minum, dan pembuangan sampah yang benar. Di lain pihak, DBD juga bisa menyerang penduduk yang lebih makmur terutama yang biasa bepergian. Dari penelitian di Pekanbaru Provinsi Riau, diketahui faktor yang berpengaruh terhadap kejadian DBD ialah pendidikan dan pekerjaan masyarakat, jarak antar rumah, keberadaan tempat penampungan air, keberadaan tanaman hias dan pekarangan serta mobilisai penduduk; sedangkan tata letak rumah dan keberadaan jentik tidak menjadi faktor risiko. ${ }^{5}$

\section{Simpulan}

Epidemiologi DBD di Indonesia telah berubah dengan meningkatnya jumlah kasus dari seluruh provinsi di Indonesia, meskipun terjadi penurunan angka kematian. Kelompok usia yang terserang dengue berubah menjadi kelompok remaja dan dewasa. Perubahan epidemiologi DBD ini turut dipengaruhi oleh faktor kesehatan lingkungan.

\section{Saran}

Surveilans epidemiologi harus berlangsung baik dan terus menerus bersamaan dengan edukasi masyarakat dan program pengendalian vektor untuk mencegah transmisi. Penyuluhan mengenai $3 \mathrm{M}$ perlu lebih diintensifkan di sekolahsekolah.

\section{Daftar pustaka}

1. Hairani LK. Gambaran epidemiologi demam berdarah [Tesis]. Jakarta: Fakultas Kesehatan Masyarakat Universitas Indonesia; 2009.

2. WHO. Dengue haemorrhagic fever. Diagnosis, treatment and control. Geneva: WHO, 2009.

3. Karyanti MR, Hadinegoro SR. Perubahan epidemiologi demam berdarah dengue di Indonesia. Sari Pediatri. 2007;10(6): 424-32.

4. WHO. Dengue haemorrhagic fever. Diagnosis, treatment and control (2nd ed). Geneva: WHO, 1997.

5. Mashoedi ID. Hubungan antara distribusi serotipe virus dengue dari isolat nyamuk aedes spp dengan tingkat endemisitas demam berdarah dengue (studi kasus di Kota Semarang) [Tesis]. Semarang: Program Pascasarjana Universitas Diponegoro; 2007.

6. Lestari K. Epidemiologi dan pencegahan DBD di Indonesia. Farmaka. 2007;5(3):12-29.

7. Sumarmo. Dengue hemorrhagic fever in Indonesia. Southeast Asian J Trop Med Public Health. 1988;18:269-74.

8. Hoedojo. Vektor DBD dan upaya penanggulangannya. Majalah Parasitologi Indonesia. 1993;G(1):3145.

9. Candra A. Demam berdarah dengue: 
Epidemiologi, patogenesis, dan faktor risiko penularan. Aspirator. 2010;2: 110-9.

10. Pusat Data \& Informasi Perhimpunan Rumah Sakit Seluruh Indonesia (PDPERSI), Perilaku nyamuk Aedes aegypti. Jakarta, 2005.

11. Richards AL. The first reported outbreak of dengue hemorrhagic fever in Irian Jaya, Indonesia. Am J Trop Med Hyg. 1997;57:49-55.

12. Ahmad K. Dengue death toll rises in Indonesia. Lancet. 2004;20:956.

13. Wirahjanto A, Soegijanto S. Epidemiologi demam berdarah dengue. In: Demam Berdarah Dengue (2nd ed). Surabaya: Airlangga University Press, 2006: p. $1-10$.

14. Samsi TK. Demam berdarah dengue. Pengamatan klinik dan penata- laksanaan di Rumah Sakit Sumber Waras, Bagian Ilmu Kesehatan Anak Rumah Sakit Sumber Waras. Jakarta: Universitas Tarumanegara, 2001.

15. Wibisono BH. Studi epidemiologis demam berdarah Dengue Oktober 1995 pada orang dewasa. Medika. 1995;XXI(10): 767.

16. Yamada KI, Takasaki T, Nawa $M$, Nakayana M, Arai YT, Morimoto K, et al. 2000. Demographic feaures of imported dengue fever cases serodiagnosed in Japan during 2000. Dengue Bull. 2000;24:42-5.

17. Hadi S, Yuniarti RA. Pengamatan entomologi daerah endemis dan non endemis Demam Berdarah Dengue di Kabupaten Grobogan Jawa Tengah. Jurnal Kedokteran Yarsi. 2004;12(1): 52-8. 